\title{
PELATIHAN AUTOCAD DAN RAB UNTUK PENYUSUN RENCANA KERJA PEMERINTAH DESA (RKPD) KECAMATAN PAMONA PUSELEMBA
}

\author{
David S.V. L Bangguna, Ebelhart O. Pandoyu, Elisabeth O. Wuon, Pujiono, \\ Henny I. Abulebu, Marthen M. Tangkeallo
}

\author{
Fakultas Teknik Program Studi Teknik Sipil, Universitas Sintuwu Maroso Poso, \\ bangguna@gmail.com
}

\begin{abstract}
Pamona Puselemba Subdistrict consists of 11 villages, one of 19 sub-districts in Poso Regency, Central Sulawesi Province. In 2020 the number of village funds received by the village was around Rp. 960 million. The Pamona Puselemba District Government Work Plan (RKPD) drafting team appointed to prepare the design, and RAB experienced difficulties in its preparation so that the Pamona Puselemba District Government collaborated with the Faculty of Engineering, Civil Engineering Department, University of Sintuwu Maroso Poso to carry out community service activities to the RKPD drafting team. They are training on design preparation and RAB following Indonesian National Standards (SNI). The training is carried out in two stages: the first stage is training in making physical building designs using AutoCAD. The second stage is the preparation of the RAB preparation using the Indonesian National Standard (SNI). The evaluation results show that the trainees can understand all the material provided. This evident evaluation results to measure the absorption of the material by the participants and the training's success. This condition occurs because the participants' average age is between 18-27 years so that the catching power of the participants is very good and most of the participants' educational backgrounds are SMK and Computer undergraduate graduates.
\end{abstract}

Keywords: Pamona Puselemba, Training, AutoCad, RAB.

\begin{abstract}
Abstrak
Kecamatan Pamona Puselemba terdiri dari 11 desa yang merupakan salah satu dari 19 kecamatan di Kabupaten Poso Propinsi Sulawesi Tengah. Tahun 2020 jumlah dana desa yang diterima oleh desa sekitar Rp. 960 juta. Tim penyusun Rencana Kerja Pemerintah Desa (RKPD) Kecamatan Pamona Puselemba yang ditunjuk untuk menyiapkan desain dan RAB mengalami kesulitan dalam penyusunannya sehingga Pemerintah Kecamatan Pamona Puselemba bekerjasam dengan Fakultas Teknik Jurusan Teknik Sipil Universitas Sintuwu Maroso Poso untuk melakukan kegiatan pengabdian kepada masyarakat kepada tim penyusun RKPD berupa pelatihan penyusunan desain dan RAB sesuai dengan Standar Nasional Indonesia (SNI). Pelaksanaan pelatihan dilakukan dalam dua tahap yaitu: tahap pertama yaitu pelatihan pembuatan desain bangunan fisik dengan menggunakan AutoCad dan tahap kedua pelatihan pennyusunan RAB menggunakan Standar Nasional Indonesia (SNI). Dari hasil evaluasi menunjukkan bahwa peserta pelatihan dapat memahami seluruh materi yang diberikan, hal ini terlihat dari hasil evaluasi untuk mengukur penyerapan materi oleh peserta dan keberhasilan pelatihan yang dilaksanakan. Kondisi ini terjadi karena rata-rata usia peserta antara 18 - 27 tahun sehingga daya tangkap peserta sangat bagus dan sebagian besar berlatar belakang pendidikan pendidikan peserta lulusan SMK Informatika dan sarjana komputer.
\end{abstract}

Kata kunci: Pamona Puselemba, Pelatihan, AutoCad, RAB.

MARTABE : Jurnal Pengabdian Masyarakat | 222 
David S.V. L Bangguna, dkk. Pelatihan Autocad Dan Rab Untuk Penyusun ...

\section{PENDAHULUAN}

Kecamatan Pamona Puselemba terdiri dari 11 desa yang merupakan salah satu dari 19 kecamatan di Kabupaten Poso Propinsi Sulawesi Tengah. Tahun 2020 jumlah dana desa yang diterima oleh desa sekitar Rp. 960 juta (Jannah, 2020). Dengan adanya dana desa yang peruntukannya untuk pembangunan di desa, maka penggunaan dana desa tersebut harus akuntabel dan transparan. Untuk itu desa yang akan melakukan kegiatan pembangunan fisik seperti pembuatan salurand rainase, plat dueker, jembatan dan bangunan lainnya harus di desain dan dihitung penggunaan rencana anggaran biaya (RAB) untuk mengetahui kebutuhan material dan tenaga kerja. Sehingga keseluruhan biaya yang digunakan dapat dipertanggung jawabkan.

Tim penyusun Rencana Kerja Pemerintah Desa (RKPD) Kecamatan Pamona Puselemba kesulitan dalam menyiapkan desain dan RAB rencana pembangunan fisik yang telah dimusyawarahkan dan disetujui bersama oleh masyarakat desa, sehingga tim penyusun RKPD perlu di bimbing untuk menyusun desain dan RAB.

Menjawab permasalahan tersebut, maka Fakultas Teknik Jurusan Teknik Sipil Universitas Sintuwu Maroso Poso melakukan kegiatan pengabdian kepada masyarakat kepada Tim penyusun RKPD di wilayah Kecamatan Pamona Puselemba berupa pelatihan penyusunan desain dan RAB sesuai dengan Standar Nasional Indonesia (SNI).

\section{METODE PELAKSANAAN}

Pelaksanaan

kegiatan pengabdian kepada masyarakat kepada tim penyusun (RKPD) dilakukan dalam dua tahap. Tahap pertama yaitu pelatihan pembuatan desain bangunan fisik dengan menggunakan AutoCad seperti gambar 1 dibawah. Pelatihan AutoCad dilakukan langkah demi langkah yang meliputi materi 1 . menggambar garis; 2 . memilih bendabenda; 3menghapus objek; 4. menggunakan input dinamis untuk memasukkan perintah; dan 5. melakukan zoom dan telusuri. 6 . mencetak gambar.

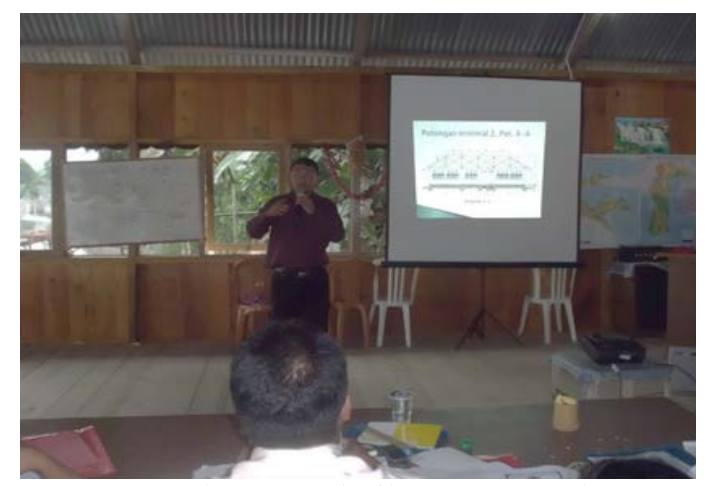

Gambar 1. Pelatihan AutoCad

Tahap kedua pelatihan pennyusunan RAB menggunakan Standar Nasional Indonesia (SNI) seperti gambar 2 dibawah. Materi pelatihan meliputi: 1 . perhitungan volume; 2 . perhitungan jumlah material yang digunakan; 3. perhitungan kebutuhan tenaga kerja; 4. perhitungan jumlah biaya yang dibutuhkan.

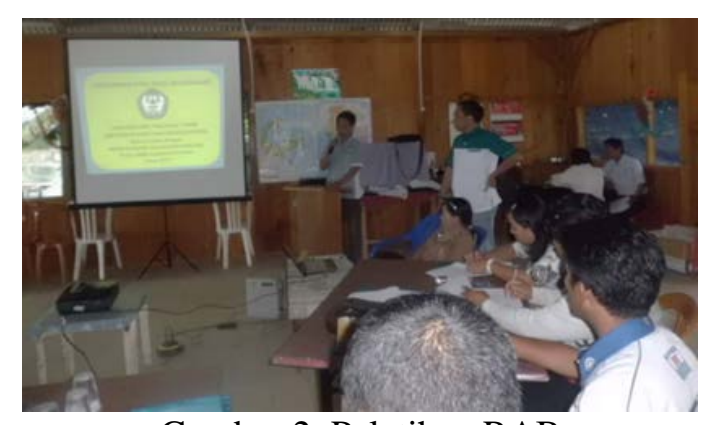

Gambar 2. Pelatihan RAB

HASIL DAN PEMBAHASAN

Pelatihan AutoCad dan penyusunan RAB dilakukan selama 6 
hari. Peserta dari tiap desa terdiri dari 2 orang, satu peserta mengikuti pelatihan AutoCad dan satu peserta lagi mengikuti pelatihan penyusunan RAB. Antusias peserta dalam mengikuti pelatihan sangat tinggi, hal ini terlihat dari indikator keberhasilan pelatihan pengabdian masyarakat yaitu:

1. Peserta pelatihan AutoCad dapat mendesain bangunan seperti desain bangunan plat dueker, riol desa, jalan desa dan desain bangunan lainnya yang akan dibangun di desa masingmasing. Desain bangunan dari hasil pelatihan AutoCad seperti ditunjukkan dalam gambar berikut.

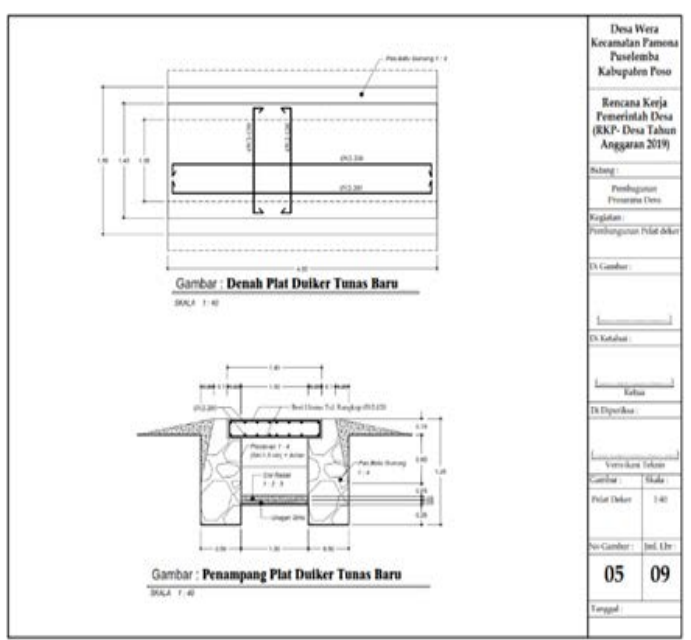

Gambar 3. Desain Plat Dueker

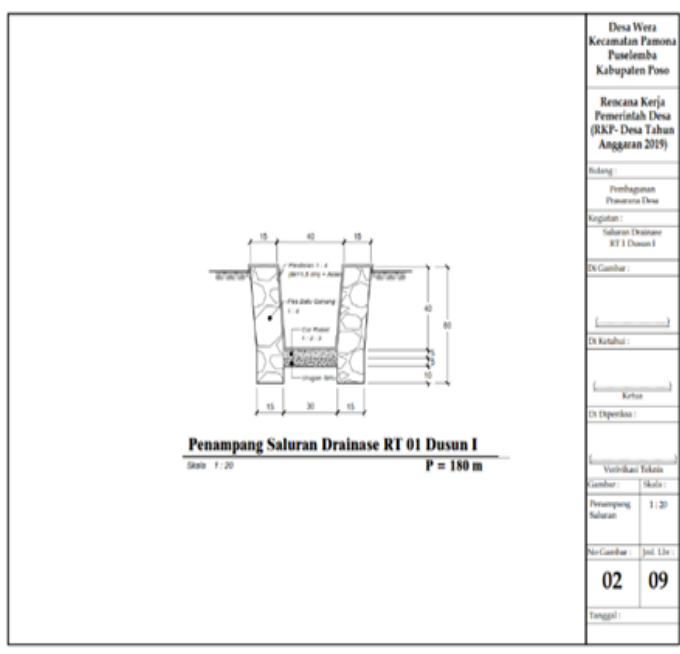

Gambar 4. Desain Riol Desa

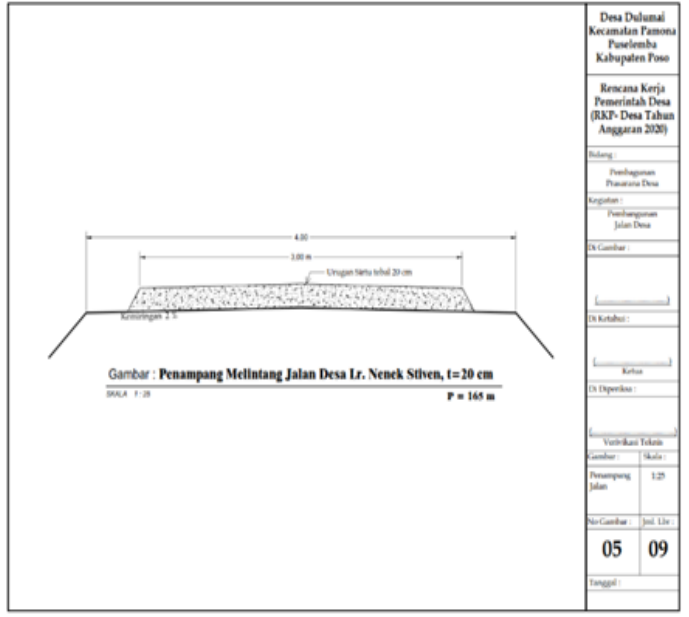

Gambar 5. Desain Jalan Desa

2. Peserta pelatihan RAB dapat menyusun Rencana Anggaran Biaya dari desain bangunan yang akan dibangun seperti ditunjukkan dalam gambar berikut.

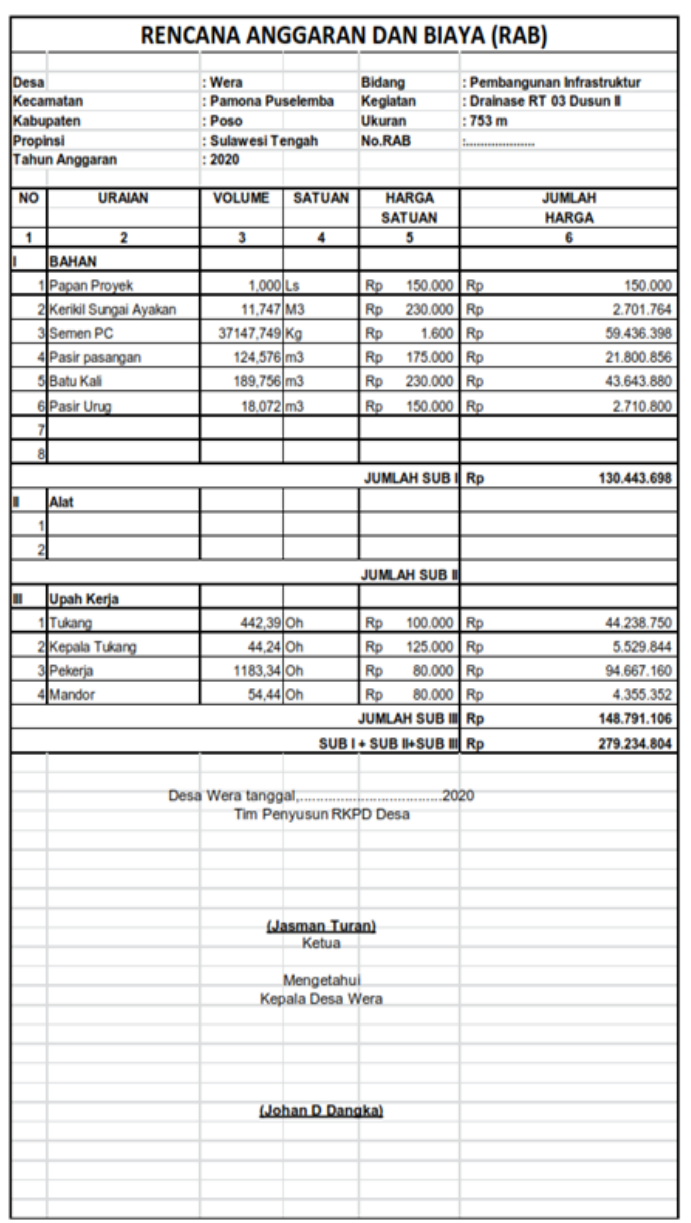

Gambar 6. RAB Drainase 
masing - masing desa sangat antusias dalam mengikuti pelatihan. Karena pelatihan yang diberikan langkah demi langkah dari toeri langsung praktek, dan tidak akan dilanjutkan kelangkah selanjutnya apabila peserta pelatihan belum mengerti materi yang diberikan. Selain itu peserta pelatihan ada timbal balik sering bertanya kepada pemateri, hal ini menunjukan bahwa materi yang diberikan sangat menarik.

Dari tahap persiapan sampai pelaksanaan pelatihan ada temuan temuan sebagai berikut:

1. Keinginan serta antusiasme pihak tim penyusun RKPD masing-masing desa menerima dengan terbuka kerja sama kemitraan pengabdian pada masyarakat dengan Fakultas Teknik Program Studi Teknik Sipil Uni versitas Sintuwu Maroso Poso.

2. Materi dan metode pembelajaran yang disampaikan cukup sederhana (teori langsung praktek). Pembuatan desain dan RAB disesuaikan dengan kebutuhan bangunan fisik yang akandibangun di desa masing-masing dengan pemahaman teori yang sederhana.

3. Kenyamanan bagi para peserta pelatihan yang dilaksanakan. dilaksanakan di Aula Desa Sangele yang menghadap ke danau Poso memberikan suasana yang sejuk dan nyaman bagi peserta pelatihan.

4. Laptop yang digunakan oleh peserta sebagian besar bukan milik peserta sendiri. Kondisi ini mengakibatkan proses belajar akan terhambat setelah laptop dikembalikan. Tetapi semangat seluruh peserta untuk belajar yang sangat tinggi.

5. Dari hasil evaluasi menunjukkan bahwa peserta pelatihan dapat memahami seluruh $\mathrm{m}$ ateri yang diberikan, hal ini terlihat dari hasil evaluasi untuk mengukur penyerapan materi oleh peserta dan keberhasilan pelatihan yang dilaksanakan (Gambar 7 dan 8). Kondisi ini terjadi karena rata-rata usia peserta antara 18 - 27 tahun sehingga daya tangkap peserta sangat bagus dan sebagian besar berlatar belakang pendidikan pendidikan peserta lulusan SMK Informatika dan sarjana komputer.

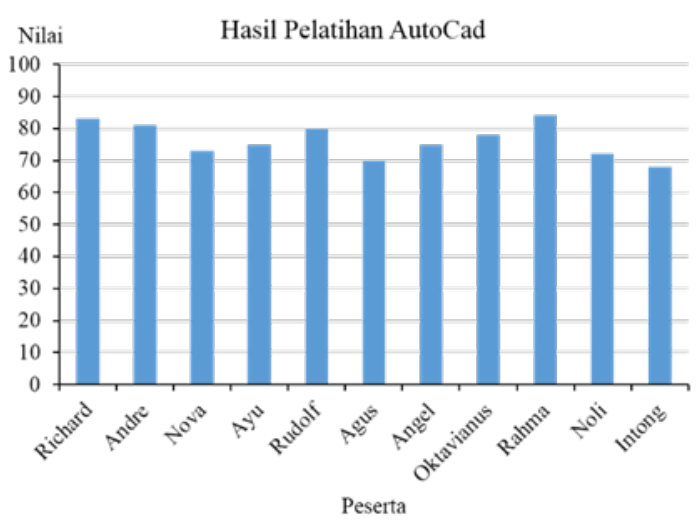

Gambar 7. Evaluasi Pelatihan AutoCad

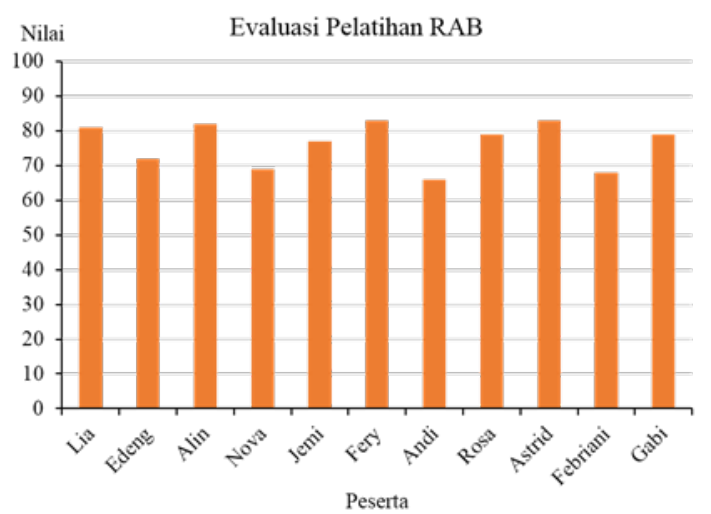

Gambar 8. Evaluasi Pelatihan RAB

\section{SIMPULAN}

Dari hasil pelaksanaan pelatihan dapat disimpulkan bahwa seluruh kegiatan pelaksanaan pelatihan berjalan dengan baik dan lancar sesuai dengan jadwal pelaksanaan. Peserta pelatihan dapat membuat desain dan menyusun RAB sesuai dengan bangunan yang akan dibangun di desa masing-masing. Sehingga tujuan program Pengabdian 
Pada Masyarakat di Kecamatan Pamona Puselemba tercapai.

\section{UCAPAN TERIMA KASIH}

Terima kasih kepada LPPM Universitas Sintuwu Maroso Poso yang telah mendanai kegiatan PKM di Kecamatan Pamona Puselemba, dan Camat serta seluruh Kepala Desa di Kecamatan Pamona Puselemba yang telah memberikan kepercayaan kepada kami untuk melaksanakan kegiatan pengabdian kepada masyarakat.

\section{DAFTAR PUSTAKA}

Anonimius, 2012. Pelatihan dan Pengembangan [online]. Tersedia: http://anahuraki.lecture.ub.ac.i d/files/2012/04/7.pelatihandan-pengembangan.pdf

Aditya Reza, 2017. Panduan Belajar AutoCad Lengkap Untuk Pemula.

https://www.arsicad.id/belajarautocad/

Argajogja's Blog, 2019. Download SNI Analisa Rencana Anggaran Biaya.

http://blogargajogja.com/rab/d ownload-sni-analisa-rencanaanggaran-biaya.html

Irwansyah, dkk. 2019. Pendampingan Pembuatan Desain Dan RAB Untuk Perangkat Gampong Dan Pemuda Karang Taruna.
Global Science Society. GSS, Vol.1, No.1 Januari-Juni 2019, Hal 31-39.

Permen Nomor 19 Tahun 2017. 2018.

Penetapan

Prioritas

Penggunaan Dana Desa.Tahun 2018, 1- 67.

Rama Kaparan, 2012. Panduan Memulai Belajar Dasar Auto CAD.

https://www.academia.edu/103 14165/Panduan_Memulai_Bela jar_Dasar_Auto_CAD

Selfie Miftahul Jannah, (2020) Dana Desa Meningkat, Tiap Desa Rata-Rata Dapat Rp 960 Juta Tahun Ini https://tirto.id/danadesa-meningkat-tiap-desa-ratarata-dapat-rp960-juta-tahunini-esQu

Tri Joko, 2018. Rencana Anggaran Biaya (RAB). https://bpsdm.pu.go.id/center/p elatihan/uploads/edok/2018/12/ 2613b_0_BAHAN_PELATIH AN_MENYUSUN_RAB_KE NDARI.pdf

Wahyudi Harianto dan Anggri Sartika Wiguna. 2020. Pelatihan Corel Draw Untuk Perangkat Desa Ngawonggo Kecamatan Tajinan. MARTABE: Jurnal Pengabdian Masyarakat Vol 3 No 1 Tahun 2020 Hal 1-4. DOI:

http://dx.doi.org/10.31604/jpm. v3i1.1-4 